\title{
MANSFIELD AND BLACKSTONE'S COMMENTARIES
}

\author{
Julian S. WATERIAN*
}

$\mathrm{I}^{1}$

N THE eighteenth century, a period when prose came to a higher excellence than it had yet attained in England, Blackstone, who lived from $I 723$ to $I 780$, rendered an unparalleled service for $j u-$ risprudence $\mathrm{x}$ in writing the Commentaries, "the prose epic of the common law."2 It has been said of this work, published from $I_{7} 6_{5}$ to I $_{7} 69$ and based on lectures at Oxford from I 753 to $I 766,3$ that the Continent derived its knowledge of English law chiefly from it, that on it the study of law in England was based, and that in America the work was regarded as the repository of the common law. ${ }^{4}$ Of Mansfield, who lived from I705 to I793, it has been said that he was not only the greatest common law judge but the greatest judge in Anglo-American legal history.5 An eminent American legal scholar said of him that "he broke down the narrow barrier of the common law" and redeemed it from "feudal selfishness and barbarity," that "he was one of those great men raised up by Providence, at a fortunate moment, to effect a salutary revolution in the world," and that "he became, what he intended, the jurist of the commercial world. . . . ."6

What were the relations in eighteenth century London between these two, the scholarly Blackstone, ${ }^{7}$ the first university lecturer on the laws of

* Dean, School of Law, University of Arkansas.

× Pancoast, English Literature (3d ed. Ig07), 403. See also Gosse, History of Eighteenth Century Literature (I89r), 307; Seccombe, The Age of Johnson (I9I4), I52; Spittal, Samuel Johnson (1923), 326; Trevelyan, History of England (I929), 5 54.

2 Gregory, Lord Mansfield, Rep. Bar Assn. of Ark. 83, 90 (r91 2).

3 Preface, I Bl. Comm.; Clitherow, Memoirs, I IVm. Bl. Rep. xvii ( $78 \mathrm{x}$ ); Roscoe, Eminent British Lawyers (1830), 251; Odgers, Blackstone, 27 Yale L. Jour. 599, 61 I (Igr8). The resignation from Oxford is set as $x 763$ by Douglas, Biographical History of Blackstone ( 1782 ), 26, 45 and I Hammond, Blackstone ( 1890 ), 57.

4 Brunner, Sources of the Law of England (Hastie's trans. I888), 45.

5 Willis, Anglo-American Law (1926), I53. Mansfield was chief justice of the King's Bench from $175^{6}$ to 1788 .

${ }^{6}$ Story, Miscellaneous Writings (I835), 262.

7 Dillon, Laws and Jurisprudence of England and America (1895), 3 ro. Sir William Blackstone is "one of the most eminent literary characters that the present age has produced." Edward Malone, Advertisement in the 1780 Supplement to Shakespeare's Plays (Johnson's and Steevens' ed., x 778 ), iii. See r Sharswood, Blackstone ( 1869 ), xvi, and 8 Foss, Judges of England (r864), 250, for Blackstone's other literary contributions, in addition to the notes on Shakespeare used by Malone. See also supra note I. 
England ${ }^{8}$ and the urbane Mansfield, a judge whose career was an epoch in English juridical history; 9 between one who, to many, is the embodiment of devotion to legal orthodoxy and the opponent of every legal reform, ${ }^{\text {xo }}$ and the other, the exemplar of judicial, if not political, liberalism? ${ }^{\text {Ix }}$ Despite the difference in their legal temperament, the fact that Mansfield's classical tastes caused him to prefer the society of scholars to that of members of his profession ${ }^{12}$ may have led to an acquaintanceship with the academic Blackstone, or perhaps their common interest in legal education fostered a friendship between the two. ${ }^{x 3}$

\section{II}

It has been said that Mansfield, as patron, ${ }^{14}$ discovered and turned to public usefulness the genius of Blackstone, then a young lawyer. ${ }^{15}$ When Blackstone, in I 753 at the age of thirty, finally decided to abandon his London practice for an academic life, partly because the profits from his profession were less than his expenses, it was Mansfield, the solicitorgeneral, who supported his application for the professorship of Roman law at Oxford. The place, however, went to one with the proper political bias after Blackstone had refused to do other than give law lectures to the best of his ability. ${ }^{16}$

${ }^{8}$ Warren, History of the American Bar (IgII), I 77 n. 2.

9 Story, supra note $6,26 \mathrm{I}$.

${ }^{10}$ Dillon, supra note 7, 297; Dicey, The Relation between Law and Public Opinion in England (I9I7), 62, 70, I26; Hicks, Men and Books Famous in the Law (I92I), I22.

Ix Pound, Interpretations of Legal History (I923), 47, x40; Dicey, supra note xo, I66; Roscoe, supra note 3, I9I.

I2 Roscoe, sulpra note 3, I7I; Boswell, Samuel Johnson (Mod. Lib. ed. x93x), 402.

${ }_{3}$ Infra note 54. Chief Justice Mansfield set aside space in the courtroom for students and stated the cases for their benefit. I Warren, History of the Harvard Law School (I908), r24. Jeremy Bentham, as a student, came to hear Mansfield, then "the head of the gods" of his idolatry. I Works of Bentham (Bowring's ed. I843), 247. See infra notes 23, 37.

See Holliday, Life of Mansfield ( 1797 ), 12-23 for two letters written by Mansfield about $x 730$ on the study of history. In 1774 Mansfield briefly outlined in a letter a course preparatory

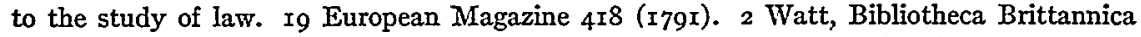
(I824), 64I f. refers to a "Treatise on the Study of Law, containing Directions to Students written by Lord Manfield and ... [others] in a Series of Letters (I797)." Holliday's biography, it is said, is by 'universal consent one of the most dull and inaccurate in the language." Buchan, Lord Mansfield, 88 Atl. Monthly 777, 778 (xgor).

${ }^{14}$ I Works of James Wilson (Andrews' ed. 1895 ), 54 n.; 383 n. 2. Bentham says Lord Shelburne was "Blackstone's making." I Works of Bentham 249. Cf. I Fitzmaurice, Life of Shelburne (1875), 312; Everett, infra note 23, I2I.

${ }^{15} 3$ Campbell, Lives of the Chief Justices (I873), 274.

${ }^{26}$ Namier, England in the Age of the American Revolution (1930), 82, 20I; Odgers, supra note 3,603. The prime minister appointed the Regius Professor of Roman Law, as the place was "crown patronage." Holdsworth, Blackstone, 7 Ore. L. Rev. 155, I57 (I927). 
It has also been stated that then, on the advice of Mansfield, ${ }^{17}$ Blackstone decided to read lectures on English law, without a university appointment, to such students as were disposed to attend them at Oxford. But Blackstone indicates that he conceived of the novel plan of teaching English law in a university and despite prejudices against educational innovations was encouraged by those in the university and out of it. ${ }^{88}$ Perhaps Mansfield was one of those out of the University who encouraged him in his private undertaking, which led to his election in $175^{8}$ as the first Vinerian professor of law at Oxford. Certainly when the professionally obscure Blackstone wished to leave the practice to become a university lecturer, Mansfield, who was politically influential, desired to aid him in achieving his ambition.

Mansfield's reactions to the published lectures of Blackstone were apparently contradictory. Blackstone stated in a letter of February, 1766 , that Mansfield had done him the honor to mark out a few of the many errors in Book One which was published in $1765^{.9}$ Mansfield, usually critical of "the authorities," law students, as he said there they would find analytical reasoning diffused in a pleasing style and that he knew no other work to recommend to them. ${ }^{2 x}$ Yet Bentham stated in 1828 in the historical introduction to the second edition of A Fragment on Government, ${ }^{22}$ a work which appeared

${ }_{17}$ MacDonell, Blackstone, 2 Dict. Nat. Biog. (Igo8), 586; 3 Mallet, History of the Univ. of Oxford (I928), x27 n. 3 .

${ }^{18}$ Preface, I Bl. Comm. Clitherow, supra note 3 , xxix, states that Blackstone resided chiefly at Oxford from I750 to I756, while composing his lectures. Sharswood, supra note 7 , xii, and Welsby, English Judges (I846), 333, state that Blackstone planned his lectures on English law about $175^{\circ}$. Since Blackstone began his lectures in 1753 he no doubt had been working on them before that year. See Douglas, supra note 3,$14 ; 4$ Encyc. Brit. (x 3 th ed. 1926), 25; Odgers, supra note 3,604; Holdsworth, Blackstone, 4 Camb. L. J. 26r, 262, 27r (r932). In the preface, however, Blackstone states that "his original plan took its rise in the year I753."

Perhaps Mansfield and others suggested in 1753 that Blackstone read the lectures on English law which he was preparing. Foss, supra note 7, 246; Holliday, supra note 13 , 89. It is often stated that it was Mansfield who furnished Blackstone the idea of lectures on English law. Hicks, supra note Io, I09; Warren, supra note 8, I $78 \mathrm{n}$.; Willis, supra note 5, I 55; Holdsworth, Charles Viner, 39 L. Quar. Rev. 17, 23 n. 4 (1923).

19 Memoirs of Wilmot (1802), 71-72. Blackstone's two letters on the Commentaries to Mr. Justice Wilmot were dated Feb. 22 and May 2, I766, when Wilmot was still on the King's Bench with Mansfield. See infra notes 33, 64 .

${ }^{20}$ Roscoe, supra note 3, 248; Wallace, infra note 43, 29.

${ }_{2 x}$ Holliday, supra note ${ }_{3}, 89$, does not give the date of Mansfield's remark. Dicey, Blackstone's Commentaries, 4 Camb. L. Jour. 286, 287 (1932), states that the remark was made about 1767 . The fourth book of the Commentaries was not published until 1769 .

${ }^{22}$ I Works of Bentham 240. The second edition of the Fragment, published in I823, did not contain the historical preface. 
anonymously in 1776 , that Mansfield was delighted by the attack on the Commentaries, an attack largely on the constitutional principles set forth in the introduction to Book One rather than on the work as a whole.23 These apparently inconsistent views of Mansfield, if he held them, can be reconciled as Mansfield could recommend the work as an introductory text for the study of "municipal law," since suitable ones were not available, and still disapprove of the constitutional principles set forth in the introduction. ${ }^{24}$

This disapprobation, if it existed, was hardly consistent with Mansfield's political philosophy. Mansfield has been considered by many as one of the leaders in the English government who fostered just prior to the Revolution reactionary foreign policies antagonistic to the American colonies. ${ }^{25}$ In fact John Quincy Adams in 1829 charged him with being more responsible for the Revolution than any other man. ${ }^{26}$ Blackstone, while

${ }^{23} \mathrm{Ibid} ., 246$. The Fragment in addition to containing an examination of the subject of government as set forth in the introduction to the Commentaries also included a short preface in which was given a critique of the work at large.

"Lord Mansfield was a rank and intolerant Tory..... He lauded the 'Fragment on Government,' not because he understood or admired the philosophy, but because it wounded Blackstone, with whom he had had a quarrel." Memoirs, ro Works of Bentham I2r. Bentham's early admiration for Mansfield waned, as in I828 he stated that the principles in the Fragment on Government stood in direct opposition to the biases of "the great Ultra-Tory." I Works of Bentham 248.

"Mansfield praised it, according to Bentham, because he disliked Blackstone." Bentham. Fragment on Government (Montague's ed. I89I), 6, editor's introd. See also Everett, The Education of Bentham (I93I), 97. Bentham also said, about 1826 , that Mansfield could not bear Blackstone. The remark refers to the period about ${ }_{7776 .} 2$ Writings of Legare ( 1845 ), 452; 10 Works of Bentham 555. Bentham stated that when the Fragment appeared anonymously it was attributed by some to Mansfield. Supra note 22.

${ }_{24}$ Mr. Justice James Wilson in his law lectures in I790 said the public law in the Commentaries should be consulted with cautious prudence but the work should be read and studied, I Works of Wilson (Wilson's ed. 1804 ), 21-22.

For a discussion of Mansfield's Tory views, see Waterman, Thomas Jefferson and Blackstone's Commentaries, 27 Ill. L. Rev. 629, 642 (r933). Jefferson considered Mansfield's legal innovations "sly poison" and dangerous to a free country, because he disapproved of judicial usurpation of legislative powers and of a non-elected judiciary curbing the jury, that "inestimable institution" which represented the people in the judicial branch. Ibid., 643; 4 Works of Jefferson (Ford's ed. 1904 ), 479, a letter of $x_{7} 89$. Jefferson also disliked Mansfield's political views. Infra note 27.

${ }_{25}$ Andrews, The Colonial Background of the American Revolution (I9'24), 208; Howard. Preliminaries of the Revolution (rgo6), r65; Mansfield, Political Chief Justice, ro7 Law Times 325 ( 1899 ); I Flanders, Lives of the Chief Justices ( 1855 ), $5 \mathrm{II}$; I Cambridge History of British Empire (I929), 632; Adams, Political Ideas of the American Revolution (I922), 24, 76; I Cooley, Blackstone (Andrews' ed. 1899 ), 96 n. 4, 97 n. 2, r44 n. 2; The Plea of the Colonies on Charges Brought against Them by Lord $M-d$ and Others ( 1775 ).

${ }^{26}$ Letters of John Quincy Adams in 2 Life and Letters of Joseph Story (W. W. Story's ed., I85x), I2, 20. Hertz, The Old Colonial System (I905), I50; Holliday, supra note I3, 247. 
not politically prominent, was considered by Jefferson ${ }^{27}$ as having produced in the Commentaries an anti-republican work which expressed the abhorrent political views ${ }^{28}$ of those in England, including Mansfield, who were opposed to democratic government. ${ }^{29}$

There are statements, much later it is true than Bentham's acid remark printed in 1828 , which cast doubt on the assertion that Mansfield was delighted with the indictment of the Commentaries, a delight, which if it existed must have come from the attack on the constitutional principles contained in the introduction to the work, as Mansfield had approved of it as a text. James DeWitt Andrews stated that Blackstone's definition of law, ${ }^{30}$ described by Mr. Justice James Wilson ${ }^{3 \mathrm{I}}$ in $\mathrm{r} 790$ as despotic and dangerous, was merely an echo of the political opinions of Mansfield. ${ }^{32}$ The same writer stated that Blackstone's view on the power of parliament over the American colonies in the first edition of Book One in 1765 contained nothing to which patriotic Americans could object, but that in $x_{7} 66$, in the second edition of Book One, the statements were changed to conform to the opinion of Mansfield and the predominant ministry in England. ${ }^{33}$

${ }^{27}$ See 12 Works of Jefferson (Ford's ed. I904), 456 , a letter of 1826 to James Madison, where
Jefferson refers to "the honied Mansfieldism of Blackstone."
". . . the high ideas of the royal prerogative with which Murray [Lord Mansfield] was in
after life identified were doubtless due to his early training." Rigg, William Murray, I3 Dict.
Nat. Biog. (I909), I307. See also Jenks, The Prerogative Writs in English Law, 32 Yale L.
Jour. 523, 534 (1922); Stansbury, Report of the Trial of James H. Peck (1883), 92; 3 Lecky,
England in the Eighteenth Century ( $\left.188_{3}\right), 54,43$.

${ }^{28}$ For Blackstone's failure to discuss constitutional law under a separate title, see Cartwright, An Appeal on the Subject of the English Constitution (1797), 28; Dicey, Constitutional Law (4th ed. I893), 7; 2 Austin, Jurisprudence (Campbell's ed. 1874), 773 .

${ }^{29}$ Andrews, supra note 25. In 1784 in The King v. Shipley, 4 Doug. 73, I72, Mr. Justice Willes, in citing the Commentaries, said "Mr. Justice Blackstone, we all know, was an antiRepublican lawyer." Erskine as counsel in the same case said: "Mr. Justice Blackstone, by no means biassed towards democratical government. . . . " Ibid., xII.

${ }^{30}$ I Bl. Comm.* 44. See Bigelow, Definition of Law, 5 Col. L. Rev. I, 3 (rgo5).

${ }^{3}$ I Wilson, supra note $\mathrm{I}_{4}, \mathrm{r}_{59} \mathrm{n}$.

32 Ibid., 54 n. See also I Hammond, supra note 3 , x12.

${ }^{33}$ Andrews, American Law ( 1900 ), \$ 42. Andrews gives Hammond as his authority for this statement. I Wilson, supra note I4, I9, editor's note; I Hammond, supra note 3, 275.

Blackstone wrote on Feb. 22, I766, to Mr. Justice Wilmot that Mansfield had suggested certain changes in Book One after its publication. In the preface to the second edition of Book One, dated Nov. 2, 1766, there is no reference to assistance from Mansfield or Wilmot. Infra note 64 .

I Hammond, supra note 3,277 , states that the reference to the threefold classification of the colonies first appeared in the second edition of Book One, published in Nov., 1766. Previously on Feb. 3, 1766, Mansfield in a speech in the House of Lords on the American colonies made a similar classification. See Holliday, supra note $\mathrm{I} 3,242$, 244; 16 Hansard, Parliamentary His- 
It seems odd that Mansfield, in view of his political philosophy and his place in the English government, should have been pleased in 5776 with Bentham's attacks on the constitutional principles appearing in the introduction to the Commentaries. Even stranger is this delight if Mansfield's definition of law appeared in the first edition of Book One and his view on the relation of parliament to the colonies, a great issue in England before 1776 , was inserted in the second edition of Book One in $x 766$. By ${ }^{1776}$ had the friendly relationship between Blackstone and Mansfield ceased? ${ }^{34}$

\section{III}

Blackstone on February 9th, $\mathrm{r} 77 \mathrm{O}$, after his success as a lecturer and commentator had brought him fame, became a justice of the Court of Common Pleas, an appointment, it is said, due to Mansfield's influence. ${ }^{35}$ This position he held until his death in $\mathrm{r}_{7} 80$, save for four months immediately after his appointment when he sat on the King's Bench. On February $\mathrm{I} 6$ th he exchanged his position with Mr. Justice Yates, who was on the King's Bench, and who, it is said, desired to avoid Chief Justice Mansfield. ${ }^{36}$ Bentham stated in $1828,{ }^{37}$ that Blackstone in turn, after the death of Yates in June, I770, surrendered his position on the King's Bench because, being the weaker party, he was glad to slip down into the Common

tory ( $\left.18 \mathrm{I}_{3}\right), \mathrm{I}_{72-\mathrm{I} 77}$; Goodrich, British Eloquence ( 1878 ), I48; I Adams, British Orations (I884), I50.

For further discussion of parliamentary control over the colonies see Chalmers, Opinions of Eminent Lawyers (I858), 4I; Goebel, Development of Legal Institutions (I93I), 294; I Story, Commentaries on the Constitution ( $3 \mathrm{~d}$ ed. I858), $\S$ I5I; 9 Holdsworth, History of English Law (I926) 83; McIlwain, The American Revolution (I924), xo8 n.; 2 Wilson, supra note 14, $5 \circ 5$.

Blackstone's view that "non-conformity was a crime" was not due to Mansfield's influence. 4 Bl. Comm.*5o; 4 Hammond, supra note 3, 86; An Interesting Appendix to Blackstone's Commentaries (r772), 40, 152; Bentham, Comment on the Commentaries (Everett's ed. 1928), 24; Maitland, Constitutional History of England (1920), 516; I6 Hansard, op. cit., 3r9; Goodrich, op. cit., I 55; Taswell-Langmead, English Constitutional History (2d ed. I880), 750.

34 Supra note 23.

35 Zane, Five Ages of the Bench and Bar of England, I Select Essays on Anglo-American Legal History 719. Cf. Hicks, supra note 10, 132; Everett, supra note 23, 90; supra note I4.

${ }^{6}$ The conflict in Perrin v. Blake, infra note 47 , it is said, Ied Mr. Justice Yates to leave the King's Bench in I770. 4 Kent, Comm. (Lacy's ed. 1889 ), *224 n. b; Campbell, supra note I5 $33^{2}$ n. 2; 8 Foss, supra note 7, 4xx; Letters of Junius (x8Io), 208, a letter of Nov. I4, I770. The statement that Yates left the King's Bench because of dissension is discredited. See Odgers, infra note 43,548 . See also infra notes $38,49,52$.

37 I Works of Bentham 248. Bentham criticized Mansfield's egotism, his sense of superiority, his absolutism, and his "judicial legislation." 6 Works of Bentham I45; 7 ibid., 3 II; 9 ibid., 39I; II ibid., 62. John Marshall also commented on the "overbearing influence of Lord Mansfield" as chief justice of the King's Bench. Livingston v. Jefferson, I Brock. 203, 15 Fed. Cas. 660, 664 (C.C.D.Va. I8rr). 
Pleas to avoid the scornful and overpowering disposition of the Chief Justice. It is true that Blackstone, immediately after the death of Yates, requested of Chief Justice Wilmot, who sat on the King's Bench from I755 to $I 766$, that he again be appointed to the Court of Common Pleas and on June 22, I770, he succeeded Yates. ${ }^{38}$

When Blackstone served for four months in I770 with Mansfield on the King's Bench he "was always sitting in hot water" and there was "heartburning" between the two, as Bentham asserted;"39 this bad feeling must have developed during that period. In the third book of the Commentaries, published in 1768 , Blackstone said of Lord Mansfield that he was "a judge, whose masterly acquaintance with the law of nations was known and revered by every state in Europe." $4^{\circ}$ Again in I769, on one of the few occasions that Blackstone appeared as a speaker in the House of Commons, he "strenuously defended" Mansfield. ${ }^{4 x}$

In ${ }_{7} 744$ Mansfield said "we must not always rely on the words of reports, though under great names: Mr. Justice Blackstone's Reports are not very accurate." ${ }^{2}$ It has been said that Blackstone intended to subject his notes to a necessary revision; yet in his will he directed that they be published after his death and therefore in 1780 they were printed. ${ }^{43}$ The first edition perhaps justified Mansfield's remark, as "the reports of cases in the first volume, which were taken by Blackstone while at the bar, are often rough and incomplete-sometimes even ungrammatical." 44 Mans-

${ }^{8}$ Yates perhaps transferred to the Common Pleas because of his physical condition. Blackstone desired to serve on that court before he went on the King's Bench. I Jones, Blackstone (I915), xxii; Roscoe, supra note 3, 230, 233; Douglas, supra note 3, 32. x Wendell, Blackstone (I854), xxiii, says the Court of Common Pleas "was looked upon as a retreat from active life."

39 I Works of Bentham 248; supra note 23. Cf. infra note 54 .

${ }^{40} 3$ Bl. Comm.* 7o. See also I Jones, Blackstone (I9I 5 ), $42 \mathrm{n}$. m, for another favorable reference to Mansfield.

4 Roscoe, supra note 3, 203; 16 Hansard, supra note 33, 542, proceedings of Feb. I, I 769 , on the expulsion of John Wilkes.

${ }^{42}$ Hassells v. Simpson, I Doug. 89,93 n. (I 784$)$.

${ }^{43}$ Odgers, Blackstone, 28 Yale L. Jour. 542, 559 (r9r9); Clitherow, supra note 3, xxviii; Douglas, Catalogue of Works of Blackstone (I782), I40-r46. Clitherow, the editor of the posthumous reports, was given permission by Lord Mansfield in I780 to compare part of Blackstone's notebooks with some official papers. Douglas, supra note 3, I04.

Odgers, $o p$. cit., states that the first edition of Blackstone's Reports appeared in $178 \mathrm{r}$. The life of Blackstone by James Clitherow, which appears in I W. Bl. ( $178 \mathrm{I})$, i-xxxi, is dated Feb. 20 , $178 \mathrm{r}$. Others state that there was a 1780 edition which was reprinted in $178 \mathrm{I}$. Wallace, The Reporters (3d ed. rev. 1855), 277; Bridgman, Legal Bibliography (r807), I9; Clarke, Bibliotheca Legum (1819), 349; I Watts, supra note 13, xr8v; Marvin, Legal Bibliography (1847), 126; Hicks, supra note 10, 132. A second edition appeared in 1828 .

${ }_{44}$ Odgers, supra note 43. See also Preface, I W. BI. (2d. ed.I 828), iii-v. Veeder, The English Reports, I5 Harv. L. Rev. I, 20 (I90I): "William Blackstone's miscellaneous collection of 
field's comment, however, does not necessarily reveal any ill will, for if there had been enmity between the two, Mansfield more likely would have been far more critical as he was seldom sparing in his remarks about the reporters..$^{45}$ Furthermore, he need not have described Blackstone, as early as 1784 , as having a great name..$^{46}$

\section{IV}

A discussion of Blackstone's career as a justice inevitably involves consideration of Perrin v. Blake, ${ }^{47}$ in which Mansfield attempted to restate the rule in Shelley's Case..$^{8}$ The controversy, so virulent in nature, which centered about the actions of Mansfield in this famous case makes it a celebrated one in legal history ${ }^{49}$ and led to the production of an essay on contingent remainders and executory devises..$^{50}$

In the King's Bench on February 8, I770, Chief Justice Mansfield, Mr. Justice Yates dissenting, ${ }^{5 I}$ restated the historical rule in Shelley's Case as one of construction rather than of law. On writ of error to the Exchequer Chamber, Mansfield was reversed in $I 77^{2}$, a disposition rarely made of his judgments. ${ }^{52} \mathrm{Mr}$. Justice Blackstone, not appointed to the King's Bench until eight days after the decision in Perrin v. Blake, de-

cases $(1746-79)$. . . does not display the care we should expect from the celebrated commentator."

In Ackworth v. Kempe, I Doug. 4I, 43 ( 1778 ), Mansfield said: "I have a very correct report of it [Sanderson v. Baker, 3 Wils. 309 ( $(763)$ ] from Mr. Justice Blackstone's own notes which I will read." This case contained Blackstone's opinion as a justice.

45 Wallace, supra note 43,29 , states that Mansfield, more than any other judge, commented adversely on the reporters because his system of pulling up the landmarks of the law made it necessary for him to discredit the old authorities; that he was more sympathetic with Pope than Plowden, and was too independent to pursue authorities or to compare their relative weight. For Blackstone's criticism of some reports, see I Comm. ${ }^{*}$ I.

${ }_{46}^{6}$ Erskine, as counsel in $I 784$, said Blackstone was a great authority. The King v. Shipley, 4 Doug. 73, II2.

47 Perrin v. Blake, 4 Burr. 2579 (I770); I Wm. BI. 672.

${ }^{8}$ Shelley's Case I Co. Rep. 93b (I $58 \mathrm{r}$ ).

49 Campbell, sutpra note $x_{5}$, 329-337; Powell, Cases on Future Interests (I928), I84 n. 5I; Kales, Future Interests (r920), $\$ \$ 437,44$ r ; 24 R.C.L. 89o; Van Grutten v. Foxwell [r897], App. Cas. 658,670 .

so Fearne, An Essay on Contingent Remainders (6th ed. x8or), 238. See Hicks, Materials of Legal Research (1923), I50.

${ }^{5 x}$ Supra note 36.

52 Zane, supra note 35,718 , states that Mansfield was reversed in only two cases. See Douglas, supra note $3,33 \mathrm{n}$. and 4 Kent, supra note $36, * 224 \mathrm{n}$. b, to the effect that with the exception of Perrin v. Blake, supra note 47 , and Millar v. Taylor, 4 Burr. 2303 ( 1769 ), there was no final difference of opinion in the court in any case or upon any point whatsoever from 1756 to $r 776$.

John Adams said in $177 \mathrm{r}$ that the unanimity of the King's Bench from 1756 , due to fear of 
livered an elaborate opinion ${ }^{53}$ not in accord with Mansfield's views, which, it has been said, was the chief factor in reversing Mansfield and on which, it is said, his reputation as a lawyer depends even more than upon his Commentaries. ${ }^{54}$

John Chipman Gray has said of this case that "the reputation of Lord Mansfield as a commercial lawyer should not blind us to the fact that he was not equally great in the law of real property. For instance, his decision on the rule in Shelley's Case in Perrin v. Blake . . . . is now universally admitted to have been wrong."

The decision reveals that in the law of real property Blackstone followed the legal authorities rather than Mansfield's tendency to restate the older doctrines on the basis of equitable principles. ${ }^{56}$ Moreover, it shows on the part of Blackstone, described by Bentham as "the weaker party," independence of judgment in a branch of law the rules of which had been long worked out. 57

Lord Mansfield, the Scottish chief, was a miracle in the moral and intellectual world. 4 Works of Adams (Adams' ed. 1850), 257. See 4 Burr. 2303, 2582.

In Millar v. Taylor, Blackstone's argument as counsel for the plaintiff, that despite a statute limiting the period of copyright, there was a perpetual common law copyright, was followed by the King's Bench, Mr. Justice Yates dissenting. In the House of Lords in Donaldson v. Becket, 4 Burr. 2408, 24II (I 774), Blackstone by then a justice, expressed the views he had set forth previously as counsel. Millar v. Taylor was not approved by the majority, however. The Commentaries in 1778 was changed to conform to the decision of 1774 . I Jones, Blackstone (r915), ז263 n. h. See Commons, The Legal Foundations of Capitalism (rg24), 275; I Sharswood, supra note 7, xiv; Hill, Letters of Hume to Strahan (r888), 274, a letter of I 774; 7 Eng. Rul. Cas. 69; r3 C.J. 973 .

s3 For Blackstone's opinion in the Exchequer Chamber see: Hargrave, Law Tracts ( 1787 ), 489-510; 3 Hargrave, Jurisconsult Exercitations (I8r3), 38I; ro Eng. Rul. Cas. 695. Cf. Van Grutten v. Foxwell, [1897] App. Cas. 658, 676.

st Campbell, supra note I5, $333 \mathrm{n}$.; Hicks, supra note IO, I32. "Yet this difference of opinion [in ${ }^{772}$ ] never made Lord Mansfield break out into violent sarcasms against Blackstone, and never in any way affected the friendship that so long existed between these two great lawyers." Odgers, supra note 43, 55I (I9I9). Cf. supra note 23.

$5 s$ Gray, The Rule against Perpetuities (3d ed. rgr 5 ), I69 n. 5. For a defense of Mansfield, see Holliday, supra note 13 , 190-209. See also Campbell, supra note 15, 329; Powell, supra note 49 , I84 n. 52 .

${ }^{56}{ }_{3}$ Holdsworth, History of English Law (1923), Iog; 8 Holdsworth, ibid., $45 ; 4$ Works of Jefferson, supra note 24; Shannon v. Bradstreet, I Sch. \& Lef. 52, 66 (1803); Dickinson, The Problem of the Unprovided Case, 8I Univ. Pa. L. Rev. II5, xx7 (1932); Dickinson, The Law behind the Law, 29 Col. L. Rev. 285, 3 II (x929); Story, supra note 6, 300, 3०5; Douglas, supra note 3 , v.

577 Holdsworth, supra note $56,77-78$, gives the reasons why Mansfield's attempts to restate the law of real property failed. See also Fifoot, English Law (1932), I35; Markby, Elements of Law (4th ed. I889), 230; r Evans, Decisions of Mansfield in Civil Causes (r803), 172356 . 


\section{$\mathrm{V}$}

Since Mansfield served as chief justice of the King's Bench from 1756 to $I 788,,^{8}$ an opportunity was furnished him to cite the Commentaries, which appeared from ${ }^{2} 765$ to $I 769$. If the work were authoritative, ${ }^{59}$ citing it would justify an inference that Blackstone influenced Mansfield's legal views. But since it was merely a revision of lectures given to beginning law students it is hardly to be expected that the English courts would cite it frequently as legal authority, at least not so soon after its publication. Mansfield had, as has been stated, approved of the work as an introductory law text ${ }^{60}$ and knew as did Blackstone that it was not an authoritative work. ${ }^{6 x}$ Mansfield once cited the work, without comment other than saying that it gave "the rise and history of amendments very shortly and in few words." $" 62$

Though the Commentaries were not considered as authoritative by Lord Mansfield, perhaps the daring ideas of the great chief justice of the King's Bench influenced Blackstone, the university professor. As stated, Book One had been critically read by Mansfield after its publication and errors in it pointed out to Blackstone. ${ }^{63}$ Mr. Justice Wilmot suggested a revision of this book and Blackstone sought a meeting with him

$5^{8}$ Willis, supra note $5,{ }_{54}$.

59 Jenks, History of English Law (2d ed. I922), I96; I Kent, Comm. *499; Pollock, Jurisprudence (5th ed. 1923 ), 250.

${ }^{60}$ Supra note 2I.

6r I B1. Comm. *72. Lord Chancellor Redesdale in Shannon v. Shannon, I Sch. \& Lef. 324 , 327 (I804), said: "I am always sorry to hear Mr. Justice Blackstone's Commentaries cited as an authority: he would have been sorry himself to hear the book so cited: he did not consider it such." Cf. 2 Great American Lawyers (rgo8), 498 n. $x$ r.

Blackstone described himself an "academical expounder." I Comm. *35. See also Blackstone, Law Tracts (r77r), vii; Jones, Bailments ( $178 \mathrm{I}$ ), 3; Hoffman, Course of Legal Study (I817), 90; 20 Howell, State Trials, 797.

${ }_{62}$ Rex v. Wilkes, 4 Burr. 2526, 2527 ( ${ }_{7770}$. See 3 Bl. Comm. * 407 for the passage cited.

In Atcheson v. Everitt, x Cowp. 382,387 (I775), counsel cited " 3 Bl. Comm. I58." Lord Mansfield, in the opinion, said: "Mr. Justice Blackstone, and all modern and ancient writers upon the subject distinguish between them [penal statutes and criminal laws.]" I Cowp. at 39r. Blackstone's work was cited by counsel before Mansfield in Smith v. Mapleback, I T.R. 44I, 445 ( 1786 ) and Johnstone v. Sutton, $x$ T.R. 493, $5 \mathrm{I} 8$ ( $(785)$. See also The King v. Shipley, 4 Doug. 73, IrI, I72 (I784) and Jones v. Smart, I T.R. 44, 49 ( $x_{785}$ ).

Douglas, supra note 3 , rog, states that the Commentaries "are permitted to be cited though not graced with an allocatur, even in the superior courts at Westminster." On the system of judicial licensing of reports see Hicks, supra note 50, I02; Douglas, supra note 3, 106 n.; Jenks, supra note 59, rgo; Preface, I Burr. Rep. (I $\left.76_{5}\right)$, vii.

${ }^{6}$ Supra note Ig. 
to discuss proposed changes. ${ }^{64}$ In May, $x 766$, the manuscript of Book Two, or the first part of it, was submitted to him with the suggestion that he mark in the margin errors of the grosser kind. ${ }^{65}$

From this one may infer that the academic Blackstone was not disdainful of the critical comments of the justices. Yet one would hardly expect that Mansfield, with his alleged lack of respect for the common law ${ }^{66}$ could influence Blackstone, the exemplar of legal conservatism, the faithful defender and recorder of the common law, and the uncritical worshipper of legal institutions. ${ }^{67}$ Surely in a work which was an introductory text, Blackstone would not follow legal innovations of recent origin, even though instituted by his friend and patron. As he said in Book One, a judge is sworn to maintain and expound the old law by following precedents and not to pronounce new law according to his private sentiments. ${ }^{68}$

What were the legal innovations of Mansfield, which Blackstone could incorporate into his work, if he had desired to do so? Mansfield's work, as described by Holdsworth, consisted in reducing the law merchant to a body of settled principles, in liberalizing the law of quasi-contract, and in attempting to recast the doctrine of consideration and to make the court of King's Bench a court of equity as well as a court of law. He said that being a Scotchman, Mansfield kept up his interest in Scotch law which tended to make him learned in Roman and continental law and therefore to approach the common law from the view point of a student of the broad principles of jurisprudence and not of English legal history. This led him to attempt to restate much of the common law in terms of equitable principles by reliance on foreign analogies and natural reason or justice, rather than by following precedents which were suitable for a feudal or agricultural society but ill-adapted to the needs of a commercial nation. ${ }^{69}$

${ }^{64}$ Fox, Contempt of Court (I927), 21, states that Blackstone's passage on attachment for contempt probably can be traced to the undelivered opinion of Mr. Justice Wilmot, when on the King's Bench, in a case of libel of Mansfield. Rex v. Almon, Wilm. 243 ( $\left.{ }_{7} 6_{5}\right) ; 4$ Bl. Comm. ${ }^{*} 283^{-*}$ 288. The statement rests, in part, on the fact that Blackstone submitted portions of his work to Wilmot for comment. Supra note Ig.

65 Ibid. Cf. Roscoe, supra note 3, 248.

${ }^{66} 4$ Works of Jefferson, supra note $24 ; \mathrm{x}_{3}$ Writings of Jefferson (Mem. ed. r905), I66; Junius, supra note 36 ; 3 Campbell, supra note I5, 337; 2 Story, supra note 26, 20; Waterman, supra note 24,644 .

${ }_{67}^{6}$ Dillon, supra note 7, 297; Holdsworth, Sources and Literature of English Law (1925), $15^{6 .}$

${ }^{68}$ I Bl. Comm. *69; x Street, Foundations of Legal Liability (xg06), 498 n. 8.

698 Holdsworth, supra note 56, 44-45; 3 Holdsworth, supra note 56, ro9; Zane, supra note 35, 717; Story, supra note 6, 305, 412; Plucknett, History of the Common Law (1929), I70; Pound, supra note II, 67 . 
Yet Holdsworth states that the Commentaries adopted the reasoning and results of the decisions of Lord Mansfield on commercial law, consideration, and equity..$^{\circ} \mathrm{He}$ reached this conclusion after comparing the manuscript of Blackstone's lectures at Oxford, delivered before Mansfield became chief justice, with the Commentaries, which were published about nine years after Mansfield began his legal innovations. Since the treatment of these topics in the Commentaries differs from that in the earlier lectures but is in accord with the decisions of Mansfield rendered after the lectures were prepared, Holdsworth concludes that the changes were due to the influence of those decisions.

\section{VI}

Holdsworth states that Blackstone's treatment of equity jurisprudence in the Commentaries as contrasted to those in the earlier lectures, does little more than reproduce in a connected and literary form the views expressed by Lord Mansfield in his decisions. ${ }^{7 x}$ Hammond repeats a statement that the chapter on "proceedings in equity" 72 has been said to be the work of Lord Mansfield. ${ }^{73}$ This statement, however, is not accepted by Hammond, who says that "the style and method seem to be the same with the rest of the book." "74 Hammond summarizes his view of Mansfield's influence on Blackstone's chapter on proceedings in equity in these words:

It is no doubt the object of the entire chapter to reduce all the differences between law and equity, so far as possible, to matter of mere procedure, and forward the blending of the two. Lord Mansfield was doing all he could in the courts of law to forward the same object by means of actions on the case; the equitable nature of which in the Roman sense of the term he was civilian enough to see and appreciate. . . .75

Blackstone considered the division of the English law into two systems, one of law and the other of equity; an artificial one, a separation not to be

${ }^{70}$ Holdsworth, Blackstone's Treatment of Equity, 43 Harv. L. Rev. x, ro (1930).

7x Ibid., 7, II, 28.

${ }_{72} 3$ Bl. Comm. c. 27.

${ }^{73} 3$ Hammond, supra note 3, 604. I Warren, Law Studies (3d ed. I863), 657 n. I, states that somewhere he had read the surmise that Mansfield had written that part of $3 \mathrm{Bl}$. Comm. on equity from pages 429 to 443 . The first edition of this work in 1835 it seems omits this statement. The writer was unable to secure the second edition of this book.

2 Jones, Blackstone (Igr 5), $2043 \mathrm{n}$. I states that Blackstone, having been engaged in common law and not chancery practise, "doubtless did not consider himself properly equipped by his studies or previous experience to write a pioneer treatise upon the system of equity." His treatment therefore was merely "a general sketch." For the influence of Mansfield's chancery practise upon his legal decisions, see Tumer, Equity of Redemption (193I), 94; 2 Yorke, Life of Hardwicke ( $\mathrm{I}_{\mathrm{I}} \mathrm{I} 3$ ), 51 3 ; Holdsworth, supra note 70, 8. See also Billson, Equity in Relation to Common Law (I9I7), 5-IQ; 2 Austin, supra note 28, $\$ \$ 889$, ro29; Maitland, Equity (I9I3), I 2. ${ }^{74} 3$ Hammond, supra note 3,604 . 75 Ibid. 
found in any other country in the universe..$^{76} \mathrm{He}$ did not believe, as did Lord Kames ${ }^{77}$ whose statements he was refuting, that it was the business of a court of equity to abate the rigor and harshness of the common law nor did he believe that the common law courts were characterized by harsh and illiberal principles. ${ }^{78}$ It was his belief that the courts of equity would not have been needed had the clerks of chancery and the common law judges been more liberal in interpreting the Statute of Westminster II by adapting the writ to the reason and equity of the suitor's case. ${ }^{79}$

This attempt of Mansfield to convert courts of law into courts of equity, in part by the use of the action of assumpsit, ${ }^{80}$ did not pass unnoticed at the time but led to many bitter attacks on him. ${ }^{8 x}$ And Blackstone, usually considered an opponent of legal reform, appears in a new light, for Jefferson said of Mansfield's legal innovations that they were "admirably seconded by the celebrated Dr. Blackstone." ${ }_{22}$

\section{VII}

Turning from Blackstone's treatment of equity jurisprudence which it seems was a summary of Mansfield's views, consider the treatment in the Commentaries of quasi-contract and the introduction of equitable principles into law by the use of the action of money had and received..$^{83}$ If

${ }^{76} 3$ Bl. Comm. ${ }^{*} 434,{ }^{*} 442$.

77 Henry Home, Lord Kames, a Scotsman, published "Principles of Equity" in August, 1766, which he dedicated to Mansfield. See 2 Jones, Blackstone (IgI5), 2067 n.; 3 Bl. Comm. *49 n. e. I Tytler, Life and Writings of Kames (I807), 250-257, replies to Blackstone's "censure" of the views of Kames. I Story, Equity Jurisprudence ( 13 th ed. 1886 ), I 3 disagrees with the views of Kames on equity. See also 8 Writings of Jefferson (Mem. ed. x905) 384; Io American Jurist 227 ( 1833$)$.

${ }_{78} 3 \mathrm{Bl}$. Comm. *430. See Chief Justice Wilmot's remarks in ${ }^{7} 767$ in Collins v. Blantern, 2 Wils. $34 \mathrm{I}, 350$ ( 1767$)$.

${ }_{79} 3$ Bl. Comm. * ${ }^{51}$. See Ames, Lectures on Legal History (19r3), 443; Plucknett, Case and

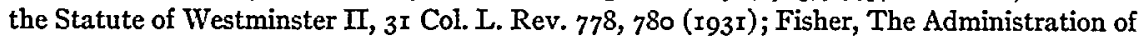
Equity through Common Law Forms, 2 Select Essays in Anglo-American Legal History 8ro, 822; Keigwin, Cases in Common Law Actions ( 1928$)$, $132 \mathrm{n}$.

${ }^{80}$ Hohfeld, The Relations between Equity and Law, ir Mich. L. Rev. 537, $5^{62}$ ( $\mathrm{Igr}_{3}$ ).

${ }_{8 t} 2$ Yorke, Life of Hardwicke (ז9r3), 512; Junius, supra note 36; Yarborough, John Horne Tooke (1926), 86; 4 Works of Jefferson, supra note 24; 2 Story, supra note 26; Douglas, supra note 3, I2r. For a defense of Mansfield's efforts to turn courts of law into courts of equity see 2 Evans, Decisions of Mansfield in Civil Causes (I803), 404; 3 Campbell, stupra note 15, 338 .

${ }_{82} 4$ Works of Jefferson, supra note 24 .

${ }^{8} \mathrm{M}$ Mansfield by fostering the action of assumpsit introduced equitable principles into the law, liberalized legal doctrines, and encroached upon equity; acts, in large part, done through the development of the law of quasi-contract. Hohfeld, supra note 8o, 562 .

Sadler v. Evans, 4 Burr. I984, I986 (I766) reads: "It [the action of money had and received] is a liberal action founded upon large principles of equity. The defence is any equity that will rebut the action." 
any English judge ever used the action of assumpsit as an instrument of legal reform it was Mansfield, ${ }^{84}$ and since he began this just prior to the publication of the Commentaries, it seems a sound inference that Blackstone's glowing tributes to this legal panace ${ }^{85} \mathrm{can}$ be traced to Mansfield's decisions.

Blackstone said of actions on the case, that where the subject matter is such as requires a determination secundum aequum et bonum the judgments of law courts are guided by the most liberal "equity" when the suit is upon an implied contract for money received to another's use, it is almost as universally remedial as a bill in equity. ${ }^{87}$ In the last chapter in Book Four, writing of the progress of the law, Blackstone commented on the liberality of sentiment, though late, which has taken possession of the courts of common law and induced them to adopt the principles of redress of our courts of equity principally by extending the remedial influence of the equitable writ of trespass on the case. ${ }^{88}$ These statements were published from 1765 to ${ }_{7} 69$.

Lord Mansfield said in Moses v. MacFerlan, decided in $1760,{ }^{89}$ that the action for money had and received was an equitable one, which is very beneficial and which ought to be encouraged, and that the gist of the action is that the defendant is obliged by the ties of natural justice and equity to refund the money. In another case in $\Upsilon_{7} 62$, Mansfield said that he had often observed that an action upon the case is almost equivalent to a bill in equity and that whatever appears upon the trial that takes away the equity will take away the remedy. ${ }^{\circ 0}$

Mansfield is generally credited with formulating the modern law of quasi-contract.9r Since this doctrine was borrowed from the Roman law, ${ }^{92}$

84 "Finally, under the influence of Lord Mansfield, the action was so much encouraged that it became almost the universal remedy where a defendant had received money which he was "obliged by natural justice and equity to refund.' " Ames, supra note 79, r64.

${ }_{85} \mathrm{Mr}$. Justice Iredell in Georgia v. Brailsford, 2 Dall. 4I5, 4I7 (I793) described the action of money had and received as the legal panacea of modern times.
${ }^{86} 3$ Bl. Comm. * 436 .
87 Ibid., *432.
${ }^{88} 4$ Bl. Comm. ${ }^{*} 442$.

${ }^{89}$ Moses v. MacFerlan 2 Burr. I005, Ior2. See I W.Bl. 2 Ig for the same case. For a discussion of the case see 3 Cook, Cases on Equity (r924), 926 n. 2; 2 Warren, supra note 73, r 352 n. 2.

For the analogy of trusts to quasi-contract see 2 Fonblanque, Equity ( 3 d ed. I807), 4 n. b; 2 Story, supra note 77, § 1255; Andrews, American Law (2d ed. I9o8), rI 2, I266; 3 B1. Comm. *432.

90 Bird v. Randall, 3 Burr. r345, I W.Bl. 387 ( 1762 ).

918 Holdsworth, supra note 56, 96-97; Woodward, The Law of Quasi-Contracts (r9I3), 2; Ames, The History of Assumpsit, 3 Select Essays in Anglo-American Legal History, 297; Walsh, History of Anglo-American Law (2d ed. r932), 349.

92 Woodward, supra note 9r, 3. Radin, Roman Law (I927), 300, cites the Roman law source from which Mansfield quoted in Moses v. MacFerlan. See 2 Bl. Comm. *443 n. g, 
it has been thought that Mansfield's views can be traced to his knowledge of that body of law and that this in turn was due to his interest in Scotch law.93 But it must be remembered that Blackstone was perhaps also versed in Roman law as he desired to become a professor in that subject at Oxford.94 It may also be argued that the concepts of natural justice and reason were so much a part of the eighteenth century legal philosophy that it is unwarranted to assume that Blackstone's view on quasi-contract is traceable toMansfield. ${ }^{95}$

Yet Blackstone's treatment of quasi-contract seems to reveal the influence of Mansfield, ${ }^{96}$ though it has been pointed out that he was confused

for a reference to the Institutes of Justinian in the discussion of quasi-contract. "An example of Lord Mansfeld's use of the Civil law will be seen in his exposition of the nature of the equitable action for money had and received, which can be traced passage by passage, to the Corpus Juris ...." Scrutton, The Influence of the Roman Law (I885), I8r. See also Corbin, QuasiContractual Obligations, 2I Yale L. Jour. 533, 545 (Igr2); Scott, Cases on Quasi-Contracts (1905), c. I; 2 Pothier, Law of Obligations (Evans' ed. 1826), app., 326-331.

937 Holdsworth, supra note 56, 44; Plucknett, supra note 69, I69. See Adam Smith, Lectures on Justice (Cannan's ed. 1896 ), 134 , where this distinguished Scotsman about 1763 used the term "quasi-contract." "It must be allowed that the introduction of quasi-contract was the highest stretch of equity, and except in the Roman law it was never perfected nor introduced." Ibid., 267. Cf. Boson v. Sandford, 3 Mod. 321, 323 (1690).

"Lord Mansfield had on his mind prejudices derived from his familiarity with the Scotch law, where law and equity are administered in the same court . . . "Shannon v. Bradstreet, I Sch. \& Lef. 52, 66 (I803).

For the influence of Mansfield's Scottish background on his attempts to convert courts of law into courts of equity, see: 2 Story, supra note 26 ; 3 Campbell, supra note 15, 338; I2 Jefferson, supra note 77; 429; Letters of Junius ( 8810 ), 206; Pollock, The Genius of the Common Law (I9I2), 83-84; Douglas, supra note 3, 33; 2 Street, supra note 68, I4I; Seccombe, supra note I, 229. Some writers state that Mansfield's Scotch education influenced his views on the common law. Scrutton, Mercantile Law (I89r), 15; Andrews, Jurisprudence and Legal Institutions $(19 \times 3)$, 359; Vance, The Early History of Insurance, 3 Select Essays in Anglo-American Legal History, rr6. Mansfield attended Westminster School, London, when fourteen and later studied at Oxford and resided in Lincoln's Inn. Campbell, supra note I5, 207-2I9. Dr. Johnson said of Mansfield's education: "Much may be made of a Scotchman, if he be caught young." Boswell, supra note I2, 425 .

94 Supra note I6. Blackstone recommended the study of Roman law. See I Bl. Comm. *33, which reads: ". . . . if lastly, he has contemplated those maxims reduced to a practical system in the laws of imperial Rome."

95 Dickinson, supra note 56, I 7 n. 2 ; Wright, The Natural Law in American Political Theory, ${ }_{4}$ S. W. Pol. Sci. Quar. 202, 204 (I923); Bryce, Studies in History and Jurisprudence (Igor), 60r; Pollock, The Law of Reason, 2 Mich. L. Rev. I59, I63 (Ig03); Ehrlich, Judicial Freedom of Decision, Science of Legal Method (x92I), 47, 67;3 Bl. Comm. * 16 I.

96 "Lord Mansfield seems to have been the first fully to appreciate the marvelous flexibility of the count for money had and received ...." 3 Street, supra note 68, 192. "Blackstone, following Lord Mansfield's creative example as a faithful expositor . . . . "Pollock, History of the Law of Nature, 2 Col. L. Rev. I31, I36 (Ig02). "The action for money had and received, which Lord Mansfield had made into a bill in equity at law . . . " Pound, Law and Morals (1923), 37. See also 2 Evans, supra note 81, 200. 
in the second book of the Commentaries as to the distinction between contracts implied in law and those implied in fact.97 It is to be noted that Blackstone quotes almost verbatim from Moses $v$. MacFerlan to which he refers in the footnotes, ${ }^{98}$ in his discussion of the action of money had and received in the third book of the Commentaries. Thus within eight years after this case was decided, which Holdsworth says summed up the law of quasi-contract and gave precision to it, its language was incorporated by Blackstone in his work. ${ }^{99}$ While Blackstone has been considered as merely recording with praise the orthodox law, in this instance he again accepted without critical comment another of Mansfield's legal innovations.

\section{VIII}

From a consideration of Mansfield's use of the action of assumpsit, and more particularly the count of money had and received, one turns to the incorporation of the law merchant into the common law..$^{200}$ In dealing with mercantile cases Mansfield once again utilized the action of assumpsit and the principle of judicial freedom of decision to accomplish his purpose. ${ }^{\text {Tox }}$

Pollock has said:

When the action of Assumpsit had enlarged not only procedure but ideas, mercantile causes could be brought before the court on the footing, not that the parties were persons subject to the law merchant, but that they had agreed to be bound by the

97 Keener, Quasi-Contracts (1893), 7-8; 2 Bl. Comm. *443.

${ }_{98}{ }_{3} \mathrm{Bl}$. Comm. ${ }^{*} \mathrm{r} 62$. A footnote by Blackstone on this page cites 4 Burr. ror2, without giving the name of the case. The reference is no doubt to Moses v. MacFerlan, 2 Burr. 1005, ror 2. Volumes one and two of Burrow's Reports were first published in four parts. Later the other three volumes by Burrow appeared. See Bridgman, supra note 43,47 ; Clarke, supra note 43,352 . This case first appeared in part four, which explains why Blackstone cited it as 4 Burr. instead of 2 Burr. Moses v. MacFerlan also appears in $r$ W.Bl. 2r9, 22r. But the paragraph of the case quoted in the Commentaries differs from that in Blackstone's own report of the case. 2 Comm., c. 30, in which Blackstone discusses contracts, is headed "title by contract" and begins with the statement that it includes "title by contract to property in things personal." For comment see Barbour, The History of Contract in Early English Equity, 4 Oxford Studies in Social and Legal History (19r4), 43 .

998 Holdsworth, supra note 56,97 .

${ }^{100}$ Scrutton, supra note 93, 14.

${ }^{\text {rox }}$ Andrews, Jurisprudence and Legal Institutions (r9r3), 352, 359, reads, "It is under the action of assumpsit that the modern law merchant has been incorporated into the common law. . . . L Lord Mansfield treating the action of assumpsit as we have just seen as an equitable action, freely and without concealment drew from the rich storehouse of the civil law for his principles of equity and justice, and it may be as plainly and truthfully stated that by this invocation of the civil law as it had developed in Europe at his time, he transformed the crude code of the common law into something like the elegance of a modern system." The relation between the law merchant and assumpsit is discussed in I Spence, Equity Jurisdiction (1846), *247. Courts of law in cases involving commercial and maritime law adopt the most enlarged and liberal principles and proceed upon the same doctrines as courts of equity. I Story, supra note 77, 3r. See also Ewart, The Law Merchant, 3 Col. L. Rev. I35, I49 (r903). 
custom of merchants. In this sense it could be said in the seventeenth century that the law merchant was part of the Common Law. Blackstone had no difficulty in adopting this statement, writing just before Mansfield's work began. ${ }^{\text {roz }}$

From this one can infer that Blackstone's treatment of the law merchant was not influenced by Mansfield's incorporation of it into the common law. But Mansfield ascended the bench in $175^{6}$, some nine years before Blackstone had completed the first book, and had already rendered his decisions in Miller $v$. Race ${ }^{\mathrm{ro3}}$ and Grant v. Vaughan, ${ }^{\mathrm{ro4}}$ leading cases in the law of bills and notes. In Luke v. Lyde, which involved a point of admiralty law, Mansfield in 1759 had said "the maritime law is not the law of a particular country, but the general law of nations." 'ros Unless Mansfield's work in incorporating the law merchant into the common law came after $I_{76}$, nine years after he became chief justice, it cannot be seen how Blackstone wrote just before Mansfield's work began.

Holdsworth has stated that Blackstone in his treatment of commercial law accepted the reasoning and results of Lord Mansfield and again supports this observation by comparing the manuscript of the earlier lectures with the Commentaries. ${ }^{\text {I06 }}$ Hammond also points out that in the first edition of Book One, Blackstone, in speaking of the law merchant, says that the law of England leaves the causes of merchants to be tried by their own peculiar customs but that the second edition states that the law merchant is held to be a part of the law of England, which decides the causes of merchants by the general rules which obtain in all commercial countries. ${ }^{\text {107 }}$

102 Pollock, supra note 93, 82. Infra note I07.

${ }^{10} 3$ Mriller v. Race, I Burr. $45^{2}$ ( $\left.175^{8}\right)$. The action in this case was trover. "This [trover] is an equitable action .... [the plaintiff] must therefore come with clean hands; according to the principle, that those who seek equity must do equity." Lord Mansfield in Fitzroy v. Gwillim, I T.R. I53, I54 (1786).

${ }^{104}$ Grant v. Vaughan, 3 Burr. ${ }_{5} 16$ ( $\mathrm{r}_{764}$ ). $\cdot$ This case is referred to in $2 \mathrm{Bl}$. Comm. ${ }_{4}^{*} 69$ merely by name. It appears in I W.Bl. 485 . See supra notes 43,98 .

${ }^{105} 2$ Burr. 882, 887; $x$ W.Bl. 19o. Scrutton, supra note 93,6 in citing this statement of Mansfield says it was made "later than Blackstone." The decision was rendered in 1759 , while the first book of the Commentaries was not published until ${ }_{7} 65$.

${ }^{106}$ Holdsworth, supra note 70 , Ir n. 45. See also Holdsworth, Blackstone, 4 Camb. L. Jour. 26r, 27I (I932).

${ }^{107}$ I Hammond, supra note $3,{ }^{*} 273 \mathrm{n}$. Cf. I Comm. ${ }^{*} 75$, where Blackstone also states that the law merchant, though a part of the common law and allowed in all commercial transactions, is used only among one set of the king's subjects. Pollock, supra note 59,287 , states that at the time Blackstone was finishing his Commentaries, the process of adopting the customs of merchants into the general law was being accomplished. Edie v. East India Co., I W.Bl. 295 ( $176 \mathrm{r}$ ), is cited to show that Mansfield held that when once a point of mercantile law was settled no particular usage should be admitted to contradict it. See Burdick, The Law Merchant, 2 Col. L. Rev. 470, 48I (r902), where it is stated that frequently the verdicts of mercantile juries were set aside by Mansfield. See also 2 Street, supra note 68, 397; Potter, Historical Introduction to English Law (1932), Igr. 
Pollock has said that since Mansfield was Scotch by birth he followed the Scottish tradition of cosmopolitan jurisprudence rather than the insular learning of the Inns of Court. ${ }^{x 8}$ Blackstone accepted this attitude as he said: "in mercantile transactions they [the courts] follow the marine law, and argue from the usages and authorities received in all maritime countries."'rog Later he said that in mercantile questions, such as bills of exchange, and in all marine causes, the law merchant, which is a branch of the law of nations, is adhered to constantly. ${ }^{\text {IIO }}$

Blackstone apparently was referring to Mansfield, when, at the end of Book Four, he spoke of the great system of marine jurisprudence, the foundations of which have been laid of late by the development of the principles of insurance law..$^{\mathrm{xx}}$ Since Mansfield is considered as having first formulated the principles of the law of insurance, there being but sixty reported cases before his day, ${ }^{\mathrm{In}}$ it seems fair to assume that Blackstone was referring to Mansfield when he said that learning on marine insurance has of late been greatly improved by a series of judicial decisions which have now established the law in such a variety of cases that if judiciously collected they would form a complete title in a code of commercial jurisprudence. ${ }^{\text {Ir3 }}$

And in commenting on the transfer of an order instrument by indorsement or a bearer one by delivery, he defends the right of the holder to recover from the maker, "contrary to the general rule of the common law that no chose in action is assignable," by the economic argument that assignment is the life of paper credit. ${ }^{114}$ And in support of the right of the

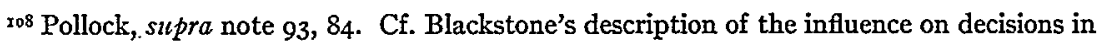
late years of the general spirit of laws and the principles of universal jurisprudence, which appeared in the preface to Book One in $x_{765}$. In Cornu v. Blackburne, 2 Doug. 64I, 648 ( $178 \mathrm{I}$ ), Lord Mansfield said, "Learned lawyers were written to on that occasion [Ricord v. Bettenham, 3 Burr. $1734,174 \mathrm{I}$ ( 1765$)$ ], both in France and Holland, and Mr. Justice Blackstone shewed me several letters he had received from abroad on the subject."

${ }^{109} 3$ Hammond, supra note $3,{ }^{*} 436 \mathrm{n}$. For the relation between the law merchant and marine jurisprudence, see Andrews, supra note Ior, 36r; Pound and Plucknett, Readings on the Common Law, 22I-223.

${ }^{110} 4$ Bl. Comm. *67. See Scott, The Legal Nature of International Law, 5 Col. L. Rev. I24, I26 (Ig05) and supra note I07.

${ }^{\text {III }} 4$ BI. Comm. * 442 .

${ }^{12}$ Park, Law of Marine Insurances ( 789 ), xl; Vance, The Early History of Insurance, 3 Select Essays in Anglo-American Legal History, II5-116; Story, supra note 6, 298.

$\mathrm{rr}_{2}{ }_{2} \mathrm{Bl}$. Comm. *460. See Park, supra note $\mathrm{xx2}$, vi.

${ }^{114}{ }_{2} \mathrm{Bl}$. Comm. ${ }_{4} 68$. Blackstone in writing of the recent progress of the laws of England stated, “. . . . the introduction and establishment of paper credit, by indorsements upon bills and notes, which have shown the legal possibility and convenience (which our ancestors so long doubted) of assigning a chose in action." $4 \mathrm{Bl}$. Comm. *442. See also 2 ibid., ${ }_{4}{ }_{4} 63$. 
holder of a bearer note to recover from the maker, Blackstone cites as authority the case of Grant $v$. Vaughan, decided by Mansfield in I764 just two years before Book Two appeared. ${ }^{x 5}$ Perhaps Blackstone's treatment of the law merchant was meager but this is to be expected in an introductory law text written about 1766 . Yet the Commentaries showed an understanding of the efforts of Mansfield to develop a code of marine jurisprudence based on the law of nations.

IX

In the field of contracts Mansfield attempted to recast the doctrine of consideration along the lines of the civil law ${ }^{156}$ by disregarding the procedural origin of consideration and by introducing principles not in accord with the older law. ${ }^{\text {IIt }}$

In 1765 in Pillans v. Van Miero $p^{\mathrm{rr} 8}$ Mansfield threw out the revolutionary suggestion that agreements should be enforceable if in writing, that the ancient notion about consideration was for the sake of evidence only, and that the want of consideration is not an objection in commercial cases. ${ }^{\text {Ing }}$ Street has said this remark of Mansfield, delivered about a year before Book Two was published, made an impression on Blackstone. ${ }^{\text {r2o }}$ In discussing consideration, Blackstone said the rule as to consideration was established because of the inconveniences arising from suits on verbal promises, for which no good reason could be assigned; therefore the rule does not hold where the promise is proved by written documents and that bonds and notes carry with them "an internal evidence of a good consideration." ${ }_{22 x}$ Holdsworth states that this view of Blackstone likewise does not appear in the lectures delivered prior to the decision of Pillans $v$. Van Mierop. ${ }^{\text {222 }}$

${ }^{135} 2$ Bl. Comm. * 469.

${ }^{x 16}$ Pollock, Contract (3d Amer. ed. I906), *I8o, says if Mansfield's views on consideration had been adopted the English law of contract would have been like that of modern civil law as adopted by the law of Scotland. Cf. 2 Street, supra note 68, I42.

${ }_{117} 8$ Holdsworth, supra note 56,34 n. 1. See also Costigan, Cases on Contracts (2d ed. I932), $x 93 \mathrm{n}$. 4. The doctrine of implied conditions, resting on equitable principles, emerged in Mansfield's opinion in Kingston v. Preston, 2 Doug. 689 ( 1773 ), four years after the last book of the Commentaries had been published. See Costigan, The Performance of Contracts ( $2 \mathrm{~d}$ ed. 1927), I0, $34,50$.

${ }^{128} 3$ Burr. 1663 ( 1765$)$. The doctrine that a bill or note requires consideration "was unknown in the time of Blackstone (2 Comm. 446)." Lorenzen, Conflict of Laws Relating to Bills and Notes (rgrg), $28 \mathrm{n} .7 \mathrm{x}$, quoting from Huffcutt, The Law of Negotiable Instruments (2d ed. I913), 325 .

198 Holdsworth, supra note 56, 29, 47. Anson, Contract (5th ed. Corbin 1930), I25.

${ }^{220}{ }_{2}$ Street, supra note 68, ${ }_{42}$ n. 4 .

${ }^{121} 2$ Bl. Comm. ${ }^{*} 445^{-*} 446$.

${ }^{322}$ Holdsworth, supra note 70, II n. 46. 
In discussing the action of assumpsit in a later book, Blackstone makes no reference to consideration, but says that a promise is in the nature of a verbal covenant and wants nothing but the solemnity of writing and sealing to make it the same. ${ }^{123}$ Hammond states that the failure to refer to consideration as an essential element of an actionable promise can only be understood by recalling Pillans $v$. Van Mierop. ${ }^{124}$ It seems clear then that Blackstone was influenced by Mansfield's attempt to recast the doctrine of consideration and adopted his evidentiary view within a few years after its appearance. ${ }^{\mathrm{I} 25}$

\section{CONCLUSION}

One writer has said that Blackstone's work was published just when Mansfield was adding an entire new area to the English common law..$^{\text {i2 } 6}$ Another has said that at the very time Blackstone was defending English law two great reformers were at work, Mansfield, by use of judicial legislation, and Bentham, who recommended legislative reforms. ${ }^{x 27}$ And still a third writer has said that Blackstone caught the spirit of his time, but just in time, as Bentham soon sounded a rude blast which disturbed the

${ }^{123} 3$ Bl. Comm. *r58. See Pollock, supra note 93, 69; Barbour, supra note 98 , 162.

${ }^{124} 3$ Hammond, supra note $3,{ }^{*}{ }_{57} \mathrm{n}$. For Wilmot's observations in Pillans v. Van Mierop on mudum pactum see 2 Street, supra note 68, I4r; Cooper, Institutes of Justinian (3d ed. I852), 588; x Evans, supra note 81, 423.

s25 On "moral obligation" in relation to "the natural justice" doctrine of quasi-contract, see Buller, Nisi Prius (1806), 130; Anson, supra note I19, 596; Holdsworth, Debt, Assumpsit,

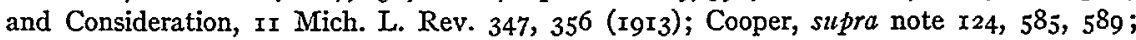
8 Holdsworth, supra note 56, 27. In 4 Ency. of Social Sciences (I93I), 233, 234, it is said that Blackstone accepted Mansfield's views on "moral obligation." Blackstone wrote, ". . . . even if the thing be founded on a prior moral obligation (as a promise to pay a just debt, though barred by the statute of limitations), it is no longer mudum pactum." 2 Comm. *445. Lorenzen, Causa and Consideration, 28 Yale L. Jour. 621,638 (rgrg), states that the doctrine of moral obligation originated in Mansfield's opinion in Hawkes v. Saunders, I Cowp. 289 ( 1782 ). Bentham, Comment on the Commentaries (Everett's ed. I928), 24, editor's introd., intimates that the doctrine first appeared in Atkins v. Hill, I Cowp. 284 ( 1775 ). These cases were decided after the Commentaries was published. In I Esp. N.P. (3d ed. I798), *95, the unreported case of Scott $v$. Nelson, decided by Mansfield in $\mathrm{r}_{7} 64$, is cited in support of the doctrine of moral obligation.

Blackstone, in his illustration, could easily have relied on the older doctrine that "the debt was considered to be a sufficient consideration for the subsequent promise," but instead be relied on the doctrine of "moral obligation." See 8 Holdsworth, silpra note 56, 26; 2 Street, supra note 68, I43; Willis, Consideration in Anglo-American Law, 72 U. of Pa. L. Rev. 245, 252 (I924). Cf. note to 3 Bos. \& Pul. 247, 249 (r802); Langdell, Summary of the Law of Contracts (1880), 89; Smith, supra note 93, 132; I Williston, Contracts (1920), 327.

${ }_{226}$ Reed, The Public Profession of the Law (I92I), 347.

${ }^{ \pm 2} 7$ Zane, supra note 35,716 . See supra note 37 for Bentham's attack on Mansfield's judicial legislation. See also Dicey, supra note Io, I66; Bentham, supra note 125, 24. 
supposed finality of the common law..$^{22}$ From these statements one may infer that Blackstone, when preparing the Commentaries, was not aware of Mansfield's work in the courts in London, or perhaps the nature of it, even though the two from $\mathrm{I}_{753}$, if not before, had been closely associated. ${ }^{\mathrm{x} 2}$

It would not be strange if the Commentaries failed to record the reforms of Mansfield, for his work as chief justice of the King's Bench, which began in 1756 , continued for twenty years after the Commentaries was published. And if Blackstone was an idolator of the past, an orthodox legalist, and an enemy of legal reform, ${ }^{130}$ surely he would not have been influenced by these revolutionary decisions of Mansfield, which were not yet rendered when he began to lecture in I753. Assuredly the legal innovations of Mansfield, a jurist who sought to develop a cosmopolitan jurisprudence based on equitable principles and foreign analogies and who was disdainful of the ancient forms and of the authorities, would not impress one of Blackstone's legal temperament nor be included in a law text a few years after their appearance. It would seem that Blackstone, a typical legal conservative, though a protégé of Mansfield, would ignore these products of judicial radicalism. ${ }^{{ }^{3 x}}$

Yet daring as these innovations were, Blackstone, the supposed defender of all accepted legal tradition, almost immediately upon their appearance and even after he had prepared his original lectures, incorporated them into his Commentaries. True, the references to them do not describe them as innovations, nor do they change the uncritical attitude of the work. Yet Blackstone was aware of the code of marine jurisprudence which Mansfield was building up; he favored the introduction of equitable

${ }^{228}$ Pollock, The Law of England, 3 L. Quar. Rev. 343, 344 (I887). Bentham attended Blackstone's lectures in 1763 , when fifteen. The Commentaries was completed in 1769 , seven years before Bentham's first published work appeared. Bentham, Fragment on Government (Montague's ed. $189 \mathrm{r}$ ), 5 , editor's introd.

129 If the friendship between Blackstone and Mansfield did terminate, it seems that this happened after 1769 , by which time the fourth book of the Commentaries had been completed. See supra note 54 .

${ }^{{ }^{3} 30}$ Bentham, The Theory of Legislation (1931),69, states that Blackstone was the enemy of every legal reform. Cf. Holdsworth, supra note 67 , 159 , which states that Blackstone introduced reforms in legal education. Accord: Thayer, Legal Essays ( 1907$), 3^{67} ; \mathrm{r}$ Jones, Blackstone (1915), xxix; Plucknett, supra note 69, 206. Blackstone was also interested in prison reform. See Everett, supra note 23, I I2; Roscoe, supra note 3, 252; Odgers, supra note 43, 554 .

See Holdsworth, Lessons from Legal History (r928), $98 \mathrm{n}$. I and Holdsworth, Historians of Anglo-American Law (1927), 57 for Blackstone's critical attitude toward many legal principles. Cf. Blackstone's views on legal education. ". . . . sciences are of a sociable disposition, and flourish best in the neighborhood of each other; nor is there any branch of learning, but may be helped and improved by assistances from other arts." I Bl. Comm. *34.

${ }^{{ }_{33}}$ I Wilson, supra note $\mathbf{4}_{4}$, 9 n. 2; Dillon, supra note $7,299$. 
principles into the law; he was not averse to turning courts of law into courts of equity; he considered the distinction between law and equity an arbitrary one; he quoted the doctrine of Mansfield's leading case in quasicontract almost verbatim; he stated that the action of money had and received could be used as a bill in equity; and he followed Mansfield's suggestion that consideration was merely evidentiary and that commercial agreements in writing did not require consideration.

If Blackstone's incorporation of Mansfield's innovations into an otherwise orthodox text be regarded as inconsistent, ${ }^{\mathrm{r} 32}$ a similar charge of inconsistency can be made against Mansfield. Mansfield defended the English colonial policy, ${ }^{133}$ which was a mercantilist one ${ }^{134}$ and such as tended to foster a national economy..$^{35}$ While Mansfield's legal opinions were an expression of a cosmopolitan jurisprudence ${ }^{\mathrm{I} 36}$ which drew its principles from the law of nations and of marine jurisprudence, he was not influenced by the developing cosmopolitan economics which Adam Smith, the Scotchman, was to summarize in The Wealth of Nations in $177^{1.37}$

${ }^{{ }^{32}}$ See 2 Ency. of Social Sciences (r93I), 580-58r, for a discussion of Blackstone's inconsistent legal and political philosophy. See also Corwin, The Higher Law Background of American Constitutional Law, 42 Harv. L. Rev. 365, 405 (I929); Dunning, Political Theories from Rousseau to Spencer (r920), 75 .

${ }^{23} 3$ Holliday, suppra note $\mathrm{I}_{3}, 246$. For praise of the mercantile system see I Bl. Comm. ${ }^{*} 274$; for a discussion of regalian rights, $i b i d .,{ }^{*} 24 \mathrm{r}$; for a defense of the navigation acts, ibid., *4r8; for statements on the evils of a tariff, ibid., *3I7. See also Haney, History of Economic Thought (Igr2), I27, n. I. For discussion of other economic views in the Commentaries see: Bentham, A Defence of Usury (2d ed. I842), 60; Hazlitt, The Spirit of the Age (4th ed. I894), I97; Sedgwick, Remarks on the Commentaries (1800), x73-224; Matsushita, Economic Effects of Public Debts (rg29), 20.

${ }^{34}$ Birney, Economic History of Europe (2d ed. 193I), 69; Williamson, A History of British Expansion (I927), 456; Schmoller, Mercantile System (I913), 79; Horrocks, Mercantilism (I925), 88; Gide and Rist, History of Economic Doctrines (2d ed. I9x5), I03; Haney, supra note $\mathrm{I} 33, \mathrm{r} 08$. 185 .

${ }_{33}$ Haney, supra note 133, 97. See 2 Smith, The Wealth of Nations (Oxford ed. 1904), $184^{-}$

${ }^{236}$ Io Halsbury, Laws of England, 259; supra note ro8.

${ }^{237}$ For a discussion of mercantile or national economy, as contrasted to the views of Smith and the Physiocrats, or cosmopolitanism, see Seligman, Principles of Economics (6th ed. I9r4), II6-ז 2x. "The most important corollaries of natural law were to them [Smith and the Physiocrats] private property and individual liberty. The liberty whose economic aspect they emphasized consisted in complete freedom in internal industry and foreign trade.". Ibid., Irg.

To the effect that the economic philosophy of the Physiocrats was based upon "natural law ideas" see: Berolzheimer, The World's Legal Philosophies (I924), 165-r 74 .

Mansfield was apparently not influenced by the Scotch economist, Adam Smith, whose best known work did not appear till I776, after Mansfield's colonial policy had been formulated. His lectures began at Glasgow as early as 1752 , however. Smith, supra note 93 , 205. For a discussion of economic thought prior to Adam Smith, see: Viner, Early English Theories of Trade, $3^{8}$ Jour. of Pol. Econ. 404, 447 (1930); 2 Muir, British Commonwealth (3d ed. 1924), r26; Chinard, Correspondence of Jefferson and DuPont de Nemours (r93r), xiii, Lxii; Malone, Cor- 
Though Mansfield dealt with the common law in a manner so as to permit it to be adjusted to shifting economic conditions $\mathrm{s}^{\mathrm{I} 38}$ and formulated a body of commercial jurisprudence which fostered exchange, his colonial policy partook of none of the economic liberalism of Adam Smith. ${ }^{\text {.39 }}$ As Mansfield's political and economic orthodoxy has been over-shadowed by his judicial liberalism; so Blackstone's adoption in the Commentaries of the former's innovations has been overshadowed by his devotion to the established order..$^{\text {I } 0}$

respondence between Jefferson and DuPont de Nemours (r93o), xiii; Adams, Political Essays of James Wilson ( 1930 ), 5 .

Birkenhead, English Judges ( 1926 ), 172 states that Mansfield was opposed to mercantilism even prior to Adam Smith. This statement rests on two early arguments of Mansfield. See $\mathbf{r}_{4}$ Hansard, supra note 33, II2, a speech on Dec. 18,1747 , and Chesterfield v. Janson, I Wils. K.B. 286,288 ( 1750 ).

${ }^{138}$ I Sherman, Roman Law in the Modern World (19I7), 382 ; Pound and Plucknett, Readings on the Common Law (I927), 223; I Flanders, supra note 25, 34-

Mansfield, in formulating his body of commercial jurisprudence, rested his decisions in part on economic policy. For example, he said: "for the sake of commerce, to which the discrediting such notes might be very detrimental" and "the consequences to trade and commerce; which would be very much incommoded by a contrary determination." See Grant v. Vaughan, 3 Burr. I516, I525 (1764) and Miller v. Race, I Burr. 452, 457 (I758).

${ }_{339}$ "A great empire has been established for the sole purpose of raising up a nation of customers. . ..." 2 Smith, supra note 135,278 . On Feb. 3,1766 , Mansfield in defending the government's colonial policy admitted that, "the Navigation Act shut up their intercourse with foreign countries. Their ports have been made subject to customs and regulations, which have cramped and diminished their trade . . ." Holliday, supra note $x_{3}, 246$.

${ }^{x^{\circ}} \mathrm{It}$ is to be expected that Blackstone, writing before Adam Smith, would express mercantilist views in his Commentaries and like Mansfield would not be influenced by the newer school of economic thought. Supra note I33. Yet an economist begins his series of readings on "the statement of the laissez-faire theory" with an excerpt from Blackstone, followed by selections from Adam Smith and Jeremy Bentham. Hamilton, Current Economic Problems (rgr 5), 90. It seems odd for the orthodox Blackstone to be classed with these two exponents of economic liberalism. Certainly nothing could have irritated Bentham more than to have been grouped with his law teacher.

Another economist has said that: "The courts have as a general thing absorbed a philosophy which is antiquated, for example, Blackstone's individualistic, eighteenth century philosophy; far more extreme in its individualism than Adam Smith's Wealth of Nations." 2 Ely, Property and Contract in Relation to the Distribution of Wealth (I9r4), 676, 708. 